\title{
The Impact of Organization Forgetting and Organization Culture on Knowledge Management in Electro Manufacture Industry
}

\author{
Gromyko Bongso ${ }^{1}$, Maruf $\mathrm{Akbar}^{2}$, and Wibowo ${ }^{3}$ \\ \{gromykobongso_im16s3@mahasiswa.unj.ac.id ${ }^{1}$ \} \\ Universitas Negeri Jakarta, Rawamangun Muka 13220, Indonesia ${ }^{1,2,3}$
}

\begin{abstract}
The electro manufacturing industry continues to grow in Indonesia. This study aims to find causal effect of organization forgetting and organizational culture relationships with knowledge management. This study uses a quantitative approach. The questionnaire in this study will be distributed to 338 employees engaged in the electro manufacturing industry. Data will be processed using an analysis tool, SPSS. The results of this study show that organizational forgetting affects knowledge management significantly and positively. Organizational culture has a significant and positive influence on knowledge management
\end{abstract}

Keywords: Knowledge Management, Organization Culture, Organization Forgetting.

\section{Introduction}

The electro manufacturing industry continues to grow as the 35,000 MegaWatt (MW) or mega project is planned. This project was initiated by the President of Indonesia which has been implemented since 2015[1]. Although this project has only been running for $10 \%$, it continues to increase demand for companies engaged in electro manufacturing. This opportunity, however, is not in line with the use of technology used in private companies engaged in electro manufacturing. The electro manufacturing industry in Indonesia starts to prioritize technological development, especially in the use of knowledge management to facilitate the process of developing knowledge for employees. The link between technology and the human resources of the company is very related.With the presence of competent human resources and being able to use information technology in business processes, the electronic manufacturing industry can take many opportunities to develop.

Knowledge management capture the information from external or internal. The information is absorbed, digested, positioned and integrated into an organization. Then the organization will create a new meaning of information, share alternative meanings and resctucture alocate new meanings. Knowledge management conditioned by organizational culture, because the value and norms held by organizational member as a filter in the sense-making and meaningconstruction processes [2]. Previous research also states that organizational culture has a positive and significant impact on knowledge management [3].

Organizational forgetting is a natural phenomenon that promotes its importance in maintaining individual knowledge [4]. Some research shows that the impact and consequences 
of organizational forgetting can actually improve organizational performance by eliminating ineffective processes or actions and learning new processes [5]. Some examples of organizational forgetting indicate that it is one that drives the distribution of knowledge within the company. In the electronics manufacturing industry, they require the correct knowledge management. With knowledge management, every company can educate new employees with knowledge, experience of seniors (tacit knowledge), or through information modules (explicit knowledge) made by the company. The research related to the electro manufacturing industry in Indonesia is quite scarce especially those regarding knowledge management.

\section{Literature Review}

\subsection{Knowledge Management}

Knowledge management is the process of organizing and distributing the collective knowledge of an organization so that the right information is conveyed to the right person at the right time [6]. By channeling the right knowledge, to the right party at a fast time so as to create interaction with each other through activities to share knowledge and application of knowledge in daily activities to improve the performance of the organization. Knowledge management is present in all organizational processes and therefore should be articulated dynamically with the strategy [7]. Whereas according to Palacios, knowledge management is a management tool characterized by a set of principles along with a series of practices and techniques through which the principles are introduced, the aim of which is to create, convert, disseminate and utilize knowledge [8].

Knowledge management is an effective learning process that is related to exploration, exploitation and various human knowledge (tacit and explicit) that uses appropriate technology and environmental culture to increase intellectual capital and organizational performance [9]. Nonaka and Takeuchi stated that knowledge is divided into 2 types, namely Explicit Knowledge and tacit knowledge. Explicit knowledge is knowledge that is coded, recorded and available and is available in databases, corporate intranets and intellectual portfolios. This knowledge is implied or documented, making it easier for employees to learn it. Examples of explicit knowledge are modules in the company for new employees that contain job descriptions or documentation of the company's business process flow. Whereas tacit knowledge is knowledge that is in people's minds. It is difficult to articulate in writing and obtained through personal experience. This knowledge is in someone who has not been documented. Tacit knowledge can be a very valuable asset for a company because it contains experience and if shared with stakeholders it can greatly help companies to overcome problems or increase knowledge. Tacit knowledge is knowledge acquired by employees from the sharing of other employees during meetings or training [10]. So that it can be concluded that knowledge management is a process of managing and distributing human knowledge that is useful for companies to be a basic reference in effective decision making with indicators : human knowledge, collective knowledge, information technology, implementation technology.

\subsection{Organization Forgetting}

Martin and Phillips define Organizational forgetting as losing intentional or unintentional organizational knowledge at any level [11]. Another definition of organizational forgetting is the loss of organizational knowledge that is not planned or intended [12]. Organizational 
forgetting is the process of disposing of old practices and setting new specifications [13]. Organizational forgetting can also be defined as leaving outdated routines, norms, beliefs, procedures, policies, values and methods while acquiring and assimilating new ones to adapt to changing environments [14]. Then it can be concluded that organizational forgetting is an individual view of a positive consequence that occurs with changes in the company that occur due to loss of knowledge with indicators : intentional loss of knowledge, unintentional loss of knowledge, changes.

\subsection{Organization Culture}

Organisational culture can, however, be effectively defined as a complex entity of values, beliefs, behaviour norms, meanings and practices shared by personnel within an establishment [15]. Organizational culture can be defined as the shared, basic assumptions that an organization learn while coping with the environment and solving problems of external adaptation and internal integration that are taught to new members as the correct way to solve those problems [16]. The convergent theories about organizational culture claim that, there is a unified consolidate culture in an organization which is distinguished as something which provides constancy between cultural factors [17]. Then it can be concluded that organization culture is an individual perception that is relatively the same as a reference agreement in an organization to help all members of the company behave with indicators : assumptions framework, values framework, belief behavioral, dan reference form.

\section{Method}

The data used in this study are secondary data and primary data. The primary data used is data obtained directly from the questionnaire distributed to employees in private companies engaged in the electro manufacturing industry.

The population in this study were employees of 2 private companies engaged in the electro manufacturing industry with a total sample of 338 employees. The sampling technique used is simple random sampling.

This research is a quantitative study with multiple regression analysis using SPSS tools. Questionnaire data will use a Likert scale with a range of values from 1 to 5 .

\section{$4 \quad$ Result And Discussion}

\subsection{Hipotesis Testing}

Table 1. Coefficients

Coefficients $^{a}$

\begin{tabular}{|c|c|c|c|c|c|c|}
\hline & & \multicolumn{2}{|c|}{ Unstandardized Coefficients } & $\begin{array}{c}\text { Standardized } \\
\text { Coefficients }\end{array}$ & \multirow[b]{2}{*}{$t$} & \multirow[b]{2}{*}{ Sig. } \\
\hline \multicolumn{2}{|c|}{ Model } & $\mathrm{B}$ & Std. Error & Beta & & \\
\hline \multirow[t]{3}{*}{1} & (Constant) & -1.989 & .182 & & -10.937 & .000 \\
\hline & Organization Forgetting & .621 & .043 & .439 & 14.393 & .000 \\
\hline & Organizational Culture & .791 & .042 & .569 & 18.668 & .000 \\
\hline
\end{tabular}

a. Dependent Variable: Knowledge Management 
Based on table 1, the significance test ( $\mathrm{p}$-value) must be smaller than 0.05 . Organizational forgetting has a significant and positive effect on knowledge management with a significant value of $0,000<0,05$. Likewise with organizational culture, it influences knowledge management significantly and positively with a significant value of $0,000<0,05$.

Table 2. Anova

ANOVA $^{\mathrm{a}}$

\begin{tabular}{|ll|r|r|r|r|l|}
\hline \multicolumn{1}{|l|}{} & \multicolumn{1}{|c|}{$\begin{array}{c}\text { Sum of } \\
\text { Model }\end{array}$} & Squares & df & Mean Square & \multicolumn{1}{c|}{$\mathrm{F}$} & \multicolumn{1}{c|}{ Sig. } \\
\hline 1 & Regression & 266.886 & 2 & 133.443 & 552.116 & $.000^{\mathrm{b}}$ \\
& Residual & 80.967 & 335 & .242 & & \\
& Total & 347.853 & 337 & & & \\
\hline
\end{tabular}

a. Dependent Variable: Knowledge Management

b. Predictors: (Constant), Organizational Culture, Organization Forgetting

Table 2. Model Sumary

Model Summary

\begin{tabular}{|l|l|r|r|r|}
\hline Model & $\mathrm{R}$ & R Square & $\begin{array}{c}\text { Adjusted R } \\
\text { Square }\end{array}$ & $\begin{array}{c}\text { Std. Error of } \\
\text { the Estimate }\end{array}$ \\
\hline 1 & $.876^{\mathrm{a}}$ & .767 & .766 & .49162 \\
\hline
\end{tabular}

a. Predictors: (Constant), Organizational Culture, Organization Forgetting

\section{b. Dependent Variable: Knowledge Management}

Based on table 2 and table 3, organization forgetting and organizational culture simultaneously has a significant effect on knowledge management with p-value 0,000 which means $<0.05$. The influence of forgetting and organizational culture organizations simultaneously is 0.767 for knowledge management.

\subsection{Discussion}

The results of this study, indicate that organizations forgetting have a significant and positive effect on knowledge management. This result is in line with previous research conducted by [18]. With the existence of forgetting organization, it will eliminate the status quo in an organization which will facilitate the occurrence of knowledge management. Knowledge management can help each company to have a competitive advantage so that members of the organization can have a reference to information and knowledge provided by the company. The results of this study also confirm that organizational culture has a significant and positive effect on knowledge management with previous studies conducted [2],[3],[19]. Organizational culture also supports good knowledge management. Organizational culture owned by the company will amalgamate with the personal culture of the company's members. With an organizational culture that wants to adapt it will certainly greatly facilitate the occurrence of knowledge management in the company. 


\section{Conclusion}

Organization forgetting has a significant and positive influence on knowledge management. Organization culture also has a significant and positive influence on knowledge management. Organization forgetting and organization culture simultaneously have a positive and significant effect on knowledge management.

\section{References}

[1] CNN Indonesia, https://www.cnnindonesia.com/ekonomi/20190702183811-532408410/pembangkit-listrik-proyek-35000-mw-baru-beroperasi-10-persen/, last accessed 2018/07/02.

[2] Zheng, W., Yang, B., McLean, G.N. Lingking organizational culture, structure, strategy and organizational effectiveness: Mediating role of knowledge management. Journal of Business Research 63, 763-771 (2010).

[3] Chang, C.L, Lin, T. The role of organizational culture in the knowledge management process. Journal of Knowledge Management 19(3), 433-455 (2015).

[4] Huang, N., Wei C., Chang W,K. Knowledge management : modeling the knowledge diffusion in community of practice. Kybernetes 36(5/6), 607-621 (2007).

[5] Gilbert, P., Bobadilla, N., Gastaldi, L., Boulaire, M.L., \& Lelebina, O. Innovation, Research and Development Management. IESTE Ltd and Wiley \& Sons, Inc, US (2018)

[6] Robbins, S. P., \& Judge, T. A. Essentials of organizational behavior (10th ed). NJ: Prentice Hall, Upper Saddle River (2010).

[7] Dayan, R., Heisig, P., Matos, F. Knowledge management as a factor for formulation and implementation of organization strategy. Journal of Knowledge Management 21(2), 308-329 (2017).

[8] Palacious, D., Gill, I., Garrigos, F. The Impact of Knowledge Management on Innovation and Entrepreneurship in the biotechnology and telecommunications industries. Small Business Economics 32(3), 291-301 (2008).

[9] Jashapara,A. Knowledge Management : An Integrated Approach (2nd Edition). Prentice Hall, US (2010).

[10] North, K., \& Kumta, G. Knowledge Management : Value Creation Through Organization Learning. Springer, New York (2014).

[11] Fernandez, V., Sune, A. Organizational forgetting and its causes: an empirical research. Journal of Organizational Change Management 22 (6), 620-634 (2009).

[12] Aydin, E., Gormus, A.S. Does organizational forgetting matter ? Organizational survival for life coaching companies. The Learning Organization 22(3), 150-162 (2015).

[13] Tsang, E.W.K, \& Zahra, S. Organizational Unlearning. Human Relations 61 (10), 1435-1462 (2008).

[14] Huang, D., Chen, S., Zhang, G., Ye J. Organizational forgetting, absorptive capacity and innovation performance. Management Decision 56(1), 87-104 (2018).

[15] Robbin, S. Organizational Behavior. Prentice-Hall, US (2004).

[16] Al-Alawi, A.I., Al-Marzooqi, N.Y., Mohammed, Y.F. Organizational culture and knowledge sharing : critical success factors. Journal of Knowledge Management 11(2), 22-42 (2007).

[17] Allameh, M., Zamani, M., Davoodi, S.M.R. The Relationship between organizational culture and knowledge management (A Case Study : Isfahan University). Procedia Computer Science 3, pp. 1224-1236. Elsevier Ltd, Iran (2011).

[18] Nafei, W. A. The Impact Of Organizational Forgetting On Knowledge Management: Evidence From Pharmaceutical Industry In Egypt. International Business Research 10(11), 193-205 (2017). 
[19] Ahmady, G.A., Nikooravesh, A., Mehrpour,M. Effect of organizational culture on knowledge management based on Denison model. 3rd International Conference on New Challenges in Management and Organization : Organization and Leadership. Procedia - Social and Behavioral Sciences 230, 387-395 (2016). 